\title{
WHITE BUILDING WORKERS AND COLOURED COMPETITION IN THE SOUTH AFRICAN LABOUR MARKET, c. 1890-1940
}

SUMMARY: The article deals with "racial" aspects of the labour market and labour relations in South Africa's building industry, focussing largely, though not exclusively, on skilled building workers on the Witwatersrand (Southern Transvaal). Different trade-union strategies are examined, as pursued by building trade unions in the Transvaal as well as the Eastern Cape and Natal, in order to add a comparative dimension. In the latter areas, shortly after World War I, a white-exclusionist organizing policy was replaced in some urban centres by a pragmatic strategy of incorporating "coloured" artisans (Africans and Indians continued to be excluded). In the Transvaal, on the other hand, the relatively strong position of white building workers and a deeply-ingrained racism ensured the maintenance of racially-exclusive trade unionism in the building industry.

\section{Introduction}

Any study of the urban labour market in South Africa in the late nineteenth and first half of the twentieth centuries will have to take account of the fact that it was marked not only by a pattern of racial stratification, but by a good deal of interracial job competition, which posed a threat to this very pattern. The ideal of white supremacists to reserve the "skilled" and "responsible" occupational positions for whites, and confine coloureds, Africans and Indians to the lower ranks of the work force, was hard to achieve in view of the dynamics of South Africa's expanding industrial labour market. For one thing, in the Cape Colony a large proportion of the skilled work in the building and manufacturing industries was performed by coloured artisans - indeed, this had been so since early colonial days. When coloured skilled workers began to migrate to other parts of South Africa, especially the Transvaal, the "coloured question" became a problem for white wage earners all over the country. Furthermore, by the 1920 s and 1930 s the proportional share of whites in the South African working class was about the same as its share in the overall population, viz. some twenty per cent. ${ }^{1}$ This meant that part of the white wage earners, in particular the so-called "poor whites", were pushed into semiskilled or even unskilled

1 Sheila T. van der Horst, "Labour", in Ellen Hellmann (ed.), Handbook on Race Relations in South Africa (Oxford, 1949), pp. 112-124.

International Review of Social History, XXXVII (1992), pp. 59-90 
jobs, where competition with non-white labour was even more severe than in the skilled trades. As a consequence, interracial competition in the labour market between whites and non-whites - as well as between different groups of non-whites - became a salient and crucial feature of South African society. Not surprisingly, this led to growing concerns about the future of the system of white domination on the part of various white social and political groups.

It stands to reason that it was first of all white wage earners who were faced with the issue of interracial labour competition and who therefore had to define their attitude toward this particular aspect of South Africa's "racial problem". The most extreme example of white workers being threatened by the competition of low-paid black labour was probably the condition in the Transvaal mining industry. White workers in the Transvaal gold mines were enforcing a "job colour bar" (partly statutory, partly informal) in an ever growing number of skilled and semiskilled occupations, to defend themselves against the tendency of the mine owners to substitute low-paid indentured African migrant workers for high-paid whites. ${ }^{2}$ However, it should be realised that, from a social point of view, the situation in the mines was far from unique, and that the struggle of white mineworkers to maintain and extend the colour bar was more than simply a rational protective device against the extreme form of competition constituted by unfree, easily manipulated and powerless Africans, who were isolated in virtually closed compounds and prevented from organizing themselves. When we focus attention on the position of the group of coloured mineworkers, of whom there were some two-thousand employed in the Transvaal mining industry by the 1920 s, it will be observed that these men were as much discriminated against by the white workers and excluded from their trade unions as were the Africans. ${ }^{3}$ Although coloureds, like whites, appeared in the labour market as free ("civilized") wage earners and were often classified as skilled or semiskilled, and although the general secretary of the white South African Mine Workers' Union admitted in 1914 that there was "a vast deal of difference" between the coloured man and the African, ${ }^{4}$ they were not treated by whites in the mining, building and many other industries as fellow-workers and denied admission to the

${ }^{2}$ Frederick A. Johnstone, Class, Race and Gold. A Study of Class Relations and Racial Discrimination in South Africa (London, 1976); Peter Richardson and Jean Jacques van Helten, "Labour in the South African gold mining industry, 1886-1914", in Shula Marks and Richard Rathbone (eds), Industrialisation and social change in South Africa. African class formation, culture, and consciousness, 1870-1930 (London and New York, 1982), pp. 77-98.

${ }_{3}^{3}$ H.J. and R.E. Simons, Class and Colour in South Africa, 1850-1950 (Harmondsworth, 1969), pp. 206, 240, 379-380.

'Dominions' Royal Commission, Minutes of Evidence, 1914, Part II (Cd. 7707): evidence by Thos. Matthews, p. 73. 
trade unions. This may go to show that white trade-union policies were not only a matter of "rational" economic self-protection, but of "irrational" race prejudice as well.

White wage earners in the skilled trades and occupations, indeed, could employ two different strategies to protect themselves against cheap nonwhite labour competition. One was to (try to) exclude non-whites from particular occupations by erecting a colour bar. ${ }^{5}$ This happened in most industries in the Transvaal and the Orange Free State, and in some trades and industries in the Cape and Natal. Another strategy was to incorporate at least the highly skilled workers among the coloured people into the unions (in some cases even semiskilled coloureds and Indians), in order to enforce the "rate for the job" and neutralize undercutting. This happened, from the second decade of the twentieth century, in many trades and industries in the Western Cape Province ${ }^{6}$, and, to a lesser extent, the Eastern Cape and Natal. There were various factors which determined what particular policy trade unions would opt for, such as the racial composition of the work force in the industry, the specific kind of (racial) division of labour and the racial and sociopolitical conditions prevailing in the area concerned. ${ }^{7}$ Of late, an economic-structural framework has tended to dominate the study of South African labour history, although a broader sociohistorical approach paying due attention to consciousness, attitudes and ideology has not been absent. ${ }^{8}$ In this paper an account will be given of struggles and trade-union strategies in the South African labour market

5 This colour bar has been referred to as "industrial colour bar" (e.g. G.V. Doxey, The Industrial Colour Bar in South Africa (Oxford, 1961)) or "job colour bar" (e.g. Johnstone, Class, Race and Gold). I think it is better to speak of "occupational colour bar", i.e. a usually informal, customary and imperfect arrangement or policy aiming at the exclusion of non-whites from specific skilled or semiskilled occupations or clusters of occupations that were seen as the preserve of white wage earners.

${ }^{6}$ Pieter van Duin, "Artisans and trade unions in the Cape Town building industry, 1900-1924", in Wilmot G. James and Mary Simons (eds), The Angry Divide. Social and economic history of the Western Cape (Cape Town, 1989), pp. 95-110.

${ }^{7}$ Cf. Jeffrey Lever, "White Organised Labour and the Development of Non-White South Africans", in W.H. Thomas (ed.), Labour Perspectives on South Africa (Cape Town, 1974), pp. 43-60; Stanley B. Greenberg, Race and State in Capitalist Development. Comparative Perspectives (New Haven, 1980), chs 12-14.

${ }^{8}$ For examples of the first approach see Jon Lewis, Industrialisation and Trade Union Organisation in South Africa 1924-55. The Rise and Fall of the South African Trades and Labour Council (Cambridge, 1984); Eddie Webster, Cast in a Racial Mould. Labour Process and Trade Unionism in the Foundries (Johannesburg, 1985). For the second approach see Elaine N. Katz, A Trade Union Aristocracy. A History of White Workers in the Transvaal and the General Strike of 1913 (Johannesburg, 1976); Charles van Onselen, Studies in the Social and Economic History of the Witwatersrand. Volume 1: New Babylon. Volume 2: New Nineveh (London, 1982). The latter work is not primarily concerned with organized workers, but with a number of "forgotten" social groups in the margin of the social structure. 
with particular reference to the relationship between white and coloured skilled workers in the Southern Transvaal, the country's industrial heartland. It will be argued that, despite the existence of a similar problem of coloured labour competition, white trade-union policies in the Transvaal on the one side, and certain centres in Natal and the Eastern Cape on the other, were completely different. ${ }^{9}$ This may demonstrate that regional differences in racial structure and sociopolitical climate were in fact as important as determining factors of trade-union policy as the labour process or economic structure.

An interesting and important example of a concrete labour market situation in South Africa, the study of which provides new insights into the question of interracial job competition, is the case of the building industry, an extremely underresearched field of South African labour history. Building and construction constituted a crucial economic activity and lends itself well for a comparative study of labour market structures and trade unionism in different regions even within South Africa itself. Moreover, the building and allied trades were the most important industry in the sphere of manufacturing and the largest urban industry in South Africa after mining. When we combine the industrial categories of building and contracting and the manufacture of building materials, we find that, by 1920-1921, the entire building industry gave employment to some 45,000 people, and by 1936-1937 to some 70,000 , overwhelmingly males. This was equal to nearly one quarter of all persons employed in manufacturing industry, and to twenty-five to thirty per cent of males. Of wage earners in the building industry some twenty-five per cent were white, while in building and contracting proper and in the woodworking trade about one-third were white ${ }^{10}$ Further, in most urban centres whites formed the majority of employees in the skilled occupations, while it was mainly coloureds, much less Indians or Africans, who were serious competitors in the skilled building trades. Thus it was mainly whites and coloureds who came into competition as building artisans.

It is of course important to probe the positions of non-white labour and white employers, the other two "class actors" in the urban labour market,

${ }^{9}$ In this paper the Western Cape, which was rather isolated from the rest of South Africa, is largely left out.

10 The figures on building and contracting and the manufacture of building materials (classes II, III and XVI in the industrial census) are from 1919-1920 somewhat inflated by the inclusion in building and contracting of persons employed on railway construction and other public works. If by means of comparison with the figures of before 1919-1920 the approximate numbers of the latter category are deducted, we arive at the figures given above. Figures for 1920-1921 and 1936-1937 are given because these were both years of relatively good employment in the building industry. See Official Year Book of the Union of South Africa, No. 2 (1918), p. 535; No. 5 (1921), p. 638; No. 20 (1939), p. 906 . 
in addition to that of white labour. The employing policies of master builders in the Transvaal were rather ambiguous. They tried to appease organized white workers, but at the same time they engaged lower-paid coloured artisans where possible. They thus helped to sustain the "split labour market", i.e. a condition whereby racially different groups of workers were paid different rates of wages for the same class of work. ${ }^{11}$ Coloured workers were forced to accept lower wages than whites, because they had a lower social status and very little political power (in the Transvaal only whites had the vote). Also, skilled coloureds were generally accustomed to a slightly lower standard of living than whites of the same social class. Indeed, in most cases coloured artisans could only find employment if they offered their labour for a lower price, since to demand the same wages as whites was tantamount to not being hired at all.

It was this last factor, indeed, which complicated matters even more than they already were. When white workers in the Transvaal discovered that attempts to eliminate coloured skilled labour from the building industry through the erection of occupational colour bars had only a limited success, they resorted to the strategy of demanding equal pay for equal work regardless of colour, but without organizing coloured workers as was done in some centres outside the Transvaal. For coloureds equal pay for equal work without trade-union protection would mean loss of employment (as employers gave preference to whites if they had to pay the same wages to all artisans), and therefore they hardly ever demanded equal wages to the whites. This in its turn further stirred up the white unions' complaints about undercutting, although it was the unions themselves that were primarily responsible for this vicious circle as long as they would not admit coloured workers to membership. The coloureds were between the devil and the deep blue sea: they would either have to accept lower wages (and incur the wrath of the white trade unions), or find no employment at all. The trade-union slogan of "equal pay for equal work" was in effect a "wage colour bar", and the more effective the "rate for the job" principle was enforced - from the second half of the 1920 s even by means of legislation the more painful the dilemma for coloured wage earners became.

In the Transvaal, where the idea of interracial cooperation was even more impopular than elsewhere in South Africa, a policy of non-racial trade-union organization was hardly ever contemplated. Indeed, every possible weapon was utilized by white building workers to oust the coloured artisan. That the latter retained their position in the labour market after all, was due to the fact that large numbers of employers were evading the payment of standard rates of wages, and to the imperfection of the in-

" Edna Bonacich, "A Theory of Ethnic Antagonism: The Split Labor Market", American Sociological Review, 37 (1972), pp. 547-559. 
struments of racial discrimination in pre-Apartheid South Africa. As it was, neither trade-union colour bars or occupational colour bars, nor wage colour bars could phase out interracial competition in the Transvaal or South African labour market.

\section{White building workers organize}

The 1890 s witnessed the first beginnings of organization among skilled white wage earners as well as employers in the Transvaal building industry. Both groups began to feel the need to consistently address their immediate economic problems and the many issues involved in their mutual relationship, including the question of interracial labour competition. The first building trade workers banding themselves together were the carpenters and joiners. After the union had been established in the coastal cities in the Cape Colony and Natal in the 1880s, the Amalgamated Society of Carpenters and Joiners (ASCJ) opened its first Transvaal branches in Johannesburg in 1893 and Pretoria in $1895 .{ }^{12}$ In 1896, the South African Operative Masons' Society and the Plasterers' Trade Union were formed, while the Bricklayers' Society and unions of plumbers and painters arrived on the scene shortly afterwards. ${ }^{13}$ Practically all the building trade unions were typical craft societies, i.e. organizations of skilled artisans that tried to protect their position as bodies of relatively privileged groups of workers by controlling the supply of skilled labour and demanding standard rates of wages for their members or all "qualified journeymen". They attempted to achieve these ends by preventing "dilution", i.e. by keeping out unskilled or semiskilled workers from their occupational sphere (except in a strictly defined subaltern role), by enforcing a "closed shop" or at least preferential employment for trade-union members, and by preserving the scarcity value of what was defined as "skilled labour" and exercising control over conditions of apprenticeship. However, it soon became evident that in South Africa the traditional craft union objectives of controlling the allocation of skilled labour and maintaining "fair" rates of wages were rather difficult to achieve. The period of scarcity of skilled labour in the late-nineteenthcentury Transvaal was coming more quickly to an end than is often thought.

${ }_{12}$ Almalgamated Society of Carpenters and Joiners' Monthly Report (Manchester), June 1893, p. 145; October 1895, pp. 263-264.

${ }_{13}$ E. Gitsham and J.F. Trembath, A First Account of Labour Organisation in South Africa (Durban, 1926), pp. 73, 162-163; Katz, A Trade Union Aristocracy, pp. 21-22, 60. Trade unionism began from small beginnings, until by 1938 there were 25,767 trade unionists in the building industry, more than 10 per cent of all organized workers in South Africa. Official Yearbook of the Union of South Africa, No. 20 (1939), p. 261. 
An alternative supply of increasingly competent non-white labour became available for those employers who sought to lower their wage costs.

By the second half of the $1890 \mathrm{~s}$, artisans in the building industry began to be nervous about competition of non-white labour. In January 1897, building workers on the Witwatersrand came out on strike against an attempted reduction of wages. ${ }^{14}$ This attack of employers on the wage standards of white artisans must have been prompted by the end of the building boom of 1891-1896, which was now turning into a depression. ${ }^{15}$ Also, in 1895 master builders in Johannesburg had formed their first association; they were now in a stronger position to confront the workers. ${ }^{16}$ However, the building workers combined their forces in the Transvaal Federated Building Trades Council, which successfully resisted the attempt to cut their wages. The interesting point about these struggles in 1897 is that the attack on the white artisans' wages was attempted, among other things, "through the use of cheap Coloured labour". ${ }^{17}$ Although in the Transvaal the term "coloured" often had the general connotation of "black" or "non-white", it may be safely assumed that it was primarily "Cape Coloured" artisans who had moved to the Rand during the building boom of the 1890 s, who were competing with white building workers and threatening to undercut their wage standards. That this competition in the skilled trades was becoming a general concern for white trade unionists in the Transvaal is indicated by the fact that shortly before the outbreak of the Anglo-Boer War in 1899, the Johannesburg Trades' and Labour Council took action against it by convening a public meeting to protest against the "employment of black skilled labour". 18

The concern about the competition of coloured, Indian or even African workers quickly rose as a point of urgency on the agenda of organized white labour. Indeed, this was the case in the building, mining, printing and other industries. In 1900, the journal of the South African Typographical Union, one of the earliest mouthpieces of organized white labour, wrote that if capitalists were allowed a "free hand", the white workers would be forced "to compete with degraded black labour - not only of South Africa but of Asia". ${ }^{19}$ As far as the building industry was concerned, it may well have been the early presence of coloured artisans in the Transvaal labour market which induced the Masons' Society to include in its rules the stipulation that

${ }^{14}$ Gitsham and Trembath, Labour Organisation, p. 16.

${ }^{15}$ Van Onselen, Studies, 11, p. 117.

${ }^{16}$ Apparently the Johannesburg Master Builders' Association was wound up later in 1897 - The South African Builder, Johannesburg Supplement, September 1932, p. xxx.

${ }^{17}$ R.K. Cope, Comrade Bill. The Life and Times of W.H. Andrews, Workers' Leader (Cape Town, 1943), p. 48.

${ }^{18}$ Katz, A Trade Union Aristocracy, p. 27.

${ }^{19}$ Ibid., p. 28. 
"no coloured apprentices shall be admitted or recognised by the Society". ${ }^{20}$ From this it would appear that the Masons were not only afraid of the actual competition of skilled or semiskilled coloureds, but in addition of the possibility that employers might train coloured youths to the ultimate detriment of the trade's white wage standards. Of course, it seems difficult to dispute that sheer race prejudice played a role as well. The Masons' Society, indeed, was one of the unions most obstinately maintaining a colour bar not only in their trade, but in the union itself. ${ }^{21}$

The Carpenters' and Joiners' Society, the most important of the building craft unions, does not seem to have had a similar colour bar rule in its constitution. Indeed, this was probably precluded by the fact that the society fell under the rules of the international organization of the ASCJ, which was based in Britain. Nevertheless, the Transvaal branches of the union left no doubt about their position on the "colour question". When in 1904 the Port Elizabeth branch of the ASCJ had the audacity to suggest that the most effective way of counteracting competition might be to organize the coloured carpenters (who formed a substantial element in the labour market in Port Elizabeth and other coastal towns), one of the two Johannesburg branches responded as follows:

We are aware that the coloured carpenter is a menace to our trade in Natal and Cape Colony, but we would urge on our members the necessity of trying to induce every white mechanic to join our ranks and combine to meet this danger. We think that should we open branches to coloured mechanics as suggested it would be the means of driving a great number of our members from the society, and it would also enable the coloured carpenter to transfer to places where they are at present non-existent and undesirable. ${ }^{22}$

One conclusion that may be drawn from this, is that the struggle against non-white competition in the Transvaal was actuated by aversion to the presence of black skilled labour per se, not only by an economic motive of self-protection. It was this refusal to regard coloured men - let alone Indians or Africans - as fellow-workers, which lay at the heart of much of the white workers' actions and social consciousness.

These attitudes came out most clearly where building trade unionists figured on federative bodies like the Witwatersrand Trades' and Labour Council and helped to define a common trade-union policy on general

${ }^{20}$ Rules of the South African Operative Masons' Society (1924). That this rule was inserted already in the earliest version of the union's constitution appears from W.H. Harrison, Memoirs of a Socialist in South Africa, 1903-1947 (Cape Town, 1947), p. 17. ${ }^{21}$ This was even the case in Cape Town - van Duin, "Cape Town building industry", pp. $99-100,106-107$.

${ }^{22}$ This resolution was passed with 26 of the 27 members present voting in favour, and none against - Amalgamated Society of Carpenters and Joiners' Monthly Report, August, 1904 , p. 382. 
social and economic questions. Men like J.J. Ware (Masons), J.E. Riley (Masons) and O.H. Evans (ASCJ), who were president of the Trades' and Labour Council in respectively 1906, 1907 and 1908, advocated racial segregation and a "White South Africa" in which labour in urban industries should be the exclusive preserve of whites. Some years later, Ware moved the adoption of a resolution by the Witwatersrand School Board that "the teaching of trades, or the use of tools, to coloured people and Natives will be sternly discountenanced". ${ }^{23}$ The expression of such sociopolitical and ideological concerns was probably encouraged by the fact that the membership of the building trade unions was not confined to construction but was spread over several industries. The Johannesburg Carpenters and Joiners, for instance, had many members on the mines, and a large proportion of the union's membership in Pretoria and Bloemfontein were employed in the Railway workshops. ${ }^{24}$ In addition, the ASCJ organized workers in the shipbuilding industry and building trade artisans in the employ of the municipalities. In 1899, it was claimed that the ASCJ had organized not more than one-tenth of the carpentry and joinery trade in South Africa, but by 1904 the society had seventeen branches in the four South African colonies and Rhodesia. ${ }^{25}$ The growth of the building trade unions particularly during the postwar boom of 1902-1904, their presence in a large number of industries, and their leading role in general trade union and labour politics encouraged the development of broader ideological concerns and turned them into a factor for employers to reckon with. But all this did not necessarily mean that they were powerful enough to prevent the increasing encroachment of coloured artisans on the field of skilled and semiskilled labour, especially when the boom passed into a long depression.

\section{The consequences of interracial competition in the Transvaal}

In 1908 the Transvaal Indigency Commission, which investigated the causes of white poverty and unemployment and the positions of white and black in the South African labour market at a time when the depression of 1904 1909 had reached its lowest point, published an alarming report. The report not only dealt with the for white South Africa so painful "poor white question", but also with the not less embarrassing problem of the competition of blacks in what were called the "skilled occupations". Both the

${ }^{23}$ Katz, A Trade Union Aristocracy, pp. 64-65, 240, 485; Simons and Simons, Class and Colour, p. 174.

${ }^{24}$ Amalgamated Society of Carpenters and Joiners' Monthly Report, September 1899, p. 317; March 1903, p. 89; April 1903, p. 146.

${ }^{25}$ Ibid., November 1899, pp. 388-389; May 1904, p. 238. 
"native" and the "coloured" population, the commission reported, were beginning to "intrude" upon the field of skilled work, and would "continue to do so". Indeed, it was held that even the African was rapidly qualifying himself to enter into competition with the white population in the skilled trades and that there were "natives who are today doing skilled work, such as attending to engines, building houses, or managing agricultural machinery". In the Transvaal, competition from the coloured population and "Asiatics" was already acute "in many branches of trade". ${ }^{26}$ One reason for this sorry state of affairs was that many kinds of skilled and semiskilled labour "which could be done by white men alone" were performed by whites with the assistance of Africans or coloured men. As a result, "the native is being educated to supplant his master". ${ }^{27}$ The commission warned that the future of the white race in South Africa depended upon "its numbers bearing a constantly increasing proportion" to those of the "natives". Therefore, the position of the white man could only be made secure "when there is a white working class upon which a part of the productive enterprise of the country depends". ${ }^{28}$

Details about the competition of non-white labour and the threat this posed to the dominant position of white wage earners in the labour market, or even to the very existence of (sections of) the white working class itself, were furnished by a host of witnesses, not the least important of whom was H.W. Sampson, who gave evidence on behalf of the Witwatersrand Trades' and Labour Council. Sampson claimed that

There has been a gradual influx into nearly all the skilled and semiskilled trades during the last few years of coloured workmen from the Cape, plasterers, carpenters, saddlers, painters, printers, tailors, bricklayers. These, of course, have supplanted white workmen, but not in any great numbers as yet. There are a great number of Indians and Chinamen employed in odd jobs in the building trades. Several specific complaints regarding this have been made to contractors and architects by the Trades Council. ${ }^{29}$

It is obvious that the presence of "Cape Coloured" artisans constituted the main threat to the position of white skilled building workers and white wage earners in a number of other trades. Replacement of whites by coloureds had not yet occurred on a large scale, but a dangerous trend had been set in motion. From Sampson's statements to the commission it also appears that

${ }^{26}$ Report of the Transvaal Indigency Commission (hereafter: TIC) (Pretoria, 1908) (T.G. 13-'08), pp. 26-28.

${ }_{27}$ TIC, p. 42. See on this point also Dominions' Royal Commission, Part II, evidence by R. Shanks, Inspector of White Labour, Johannesburg, p. 64.

28 TIC, p. 47.

29 TIC, evidence by H.W. Sampson, p. 94. Evidence was given to the Commission during the first half of 1907 . 
coloured artisans in the Transvaal received about two-thirds of the average pay of their white counterparts. ${ }^{30}$ This is corroborated by other evidence. As we shall see below, coloured wage standards ranging from fifty per cent to seventy-five per cent of those of whites were still reported in the 1920s. As for the Indians and Chinese: these were employed as painters and carpenters by small Indian and Chinese contractors who largely worked for their own people. But they also did repair work in mixed residential areas like Ferreiratown, jobs which trade unionists held should be done by white artisans at standard rates of pay. Indeed, the Trades' and Labour Council had lodged several complaints that architects had given this work to "Asiatic" contractors. ${ }^{31}$ In a similar way to the Indians and Chinese, a number of coloured artisans were working for small coloured contractors and subcontractors. Their partial confinement to employment within their own community was explained in terms of the strong prejudice against them. ${ }^{32}$

Not only on the Rand, but also in a city like Pretoria the position was rather serious. It was reported that in Pretoria coloured labour was gradually supplanting skilled and semiskilled whites in the painting and paperhanging trade, as well as in a half dozen other trades. As a result the white worker often had to fall back on unskilled labour, "and here again he is in open competition with the Kaffir at a great disadvantage"..${ }^{33}$ It was therefore advocated by several witnesses that municipalities and other public bodies should adopt a white labour policy, ${ }^{34}$ an idea that was applauded by local builders who were obviously anxious to show they had the wider interests of the white community at heart. ${ }^{35}$ It was explained to the commission that coloured skilled labour could only be kept out by "artificial restrictions". A Pretoria witness said that every obstacle was put in the way of coloureds becoming skilled workers in trades over which public bodies could exert control. These made special regulations with respect to contracts given to private employers, stipulating that no coloured skilled labour should be hired. ${ }^{36}$ In this way, by means of local government intervention, some whites might be protected, but what were the trade unions to do to counter growing competition in those cases where the open market could not be restrained?

The problem was that coloured artisans were a menace to the whites in

${ }^{30}$ Ibid., p. 96.

${ }^{31}$ Ibid.

${ }^{32}$ TIC, evidence by Colonel O'Brien, p. 64; Major Fuge, Pretoria Police, p. 108.

${ }^{33}$ TIC, evidence by Fuge, pp. 108-109, 114.

34 TIC, see for instance the evidence given by Dr. Boyd of the Pretoria Municipality, p. 120.

${ }^{35}$ See the South African Architect, Engineer and Surveyors' Journal, December 1906, p. 49; March 1907, p. 95; the South African Master Builders' Federation Journal, January 1907 , p. 29 ; July 1907 , pp. 9, 14; October 1907 , p. 19; November 1907, p. 17.

${ }^{36}$ TIC, evidence by Boyd, p. 120. 
the building trades because "all white contractors are not scrupulous in earning money and what class of workmen they employ or of the quality of the work executed". ${ }^{37}$ Sampson, enthusiastic about white labour policies though he was ${ }^{38}$ also understood that with regard to the coloured skilled worker a strategy of incorporation into the trade unions, with a view to enforcing "equal pay for equal work", might be the wisest line to pursue. Indeed, he maintained that they could keep the coloureds under control by bringing them into the unions, and pointed to the case of his own society, the Typographical Union, which had begun to organize coloured printers in the Cape. However, he admitted that in the Transvaal there was a "strong feeling" against such a policy. ${ }^{39}$ The result was that in the Transvaal a strategy of joint organization with coloured workers was never implemented in industries like building, engineering and mining. Yet there was no way of preventing groups of coloured wage earners from picking up new skills or entering the Transvaal labour market from nearby centres with a large coloured artisan class like Kimberley. It was estimated in 1907 that in Kimberley some eighty-five per cent of artisans in the building trade were coloureds, whose wages were only half of those of whites. Larger firms employing white labour to a great extent found it impossible to compete with the smaller firms that employed coloured labour almost exclusively. One of the leading builders in Kimberley reportedly said that the remedy for this cutthroat competition was to make it compulsory to pay standard rates of wages to white and coloured alike - the "best" workmen would then get the preference instead of the "cheapest". The dominating position of coloureds in the local building (and wagon building) trades seems to have come about during the preceding fifteen to twenty years. This goes to show how rapidly non-white labour could supplant the higher paid whites if the latter had no strong organizations, as was the case in Kimberley. ${ }^{40}$

\section{The policies of building-trade employers}

As against this, where white workers managed to build up relatively strong trade unions, the outcome of interracial labour competition might be different. In a leading and highly organized centre like Johannesburg, employers and white wage earners found they had certain interests in common. In 1904, Johannesburg master builders reorganized their Association, and in the same year a national organization of employers in the

${ }^{37}$ TIC, evidence by F.H. Hodkinson, p. 71.

${ }^{38}$ Sampson even suggested to the Transvaal Indigency Commission that it was possible for the white man to undertake all manual labour in agriculture - TIC, p. 93.

${ }^{39}$ TIC, evidence by Sampson, p. 96.

${ }^{40}$ TIC, memorandum submitted by the Chief Detective Inspector, Kimberley, p. 400. 
building industry was formed, the National Federation of Building Trade Employers in South Africa. ${ }^{41}$ Master Builders' Associations in the principal urban centres not only organized builders and contractors, but also subcontractors, timber merchants and owners of joinery shops, saw mills, brick and tile works, stone works and quarries. The National Federation, which repeatedly pointed out that it represented the largest industry in South Africa after mining, ${ }^{42}$ attempted to achieve a measure of stability and a standardization of wages, working conditions and organizational arrangements in the highly competitive building industry. The Johannesburg Master Builders' Association (MBA) learnt to appreciate the value of organization also on the part of the employees and strove for "conciliation" and a working relationship with the trade unions. It was emphasized that both masters and men had an interest in preventing "unfair competition" and undercutting of wages and work standards by "unscrupulous employers". After 1904 master builders showed increasing willingness to recognize the unions and enter into voluntary agreements with the organized artisans. Important elements of such agreements were the payment of standard rates of wages to all "competent" men in the different building trades and a clear definition of what was to be considered "skilled work", i.e. work to be exclusively performed by artisans. The white trade unions, indeed, became a powerful factor in the building industry, and the masters realized they could not ensure a satisfactory execution of contracts or a smooth functioning of their complicated and vulnerable industry without the unions' cooperation. The Johannesburg MBA and the National Federation tried to prove their goodwill and progressive disposition in various ways, ranging from support for new labour legislation to donations to the unions' Labour Day Committee. ${ }^{43}$

It should also be noted that many master builders in South Africa were themselves former journeymen, and that in the building industry the entry of new employers was relatively easy ${ }^{44}$ Furthermore, both builders and manufacturers and white trade unionists were interested in a policy of industrial protection to encourage local industries like carpentry and joinery, stone dressing and furniture making. This should extend the field of white employment, beside strengthening the basis of South African manu-

${ }^{41}$ South African Builder, Johannesburg Supplement, September 1932, pp. xxx-xxxi; South African Builder, National Federation Golden Jubilee Number, October 1954, p. 21.

${ }^{42}$ See for instance the South African Architect, Engineer and Surveyors' Journal, March 1907, p. 95; South African Master Builders' Federation Journal, April 1907, p. 13.

${ }^{43}$ See the Annual Reports of the Johannesburg MBA, which convey much of the niceties and intricacies of relations between masters and men.

4 To the working-class background of many a master builder frequent reference is made in reports in the Federation Journal and in other business journals. See also the Report of the Industrial Legislation Commission (U.G. 37-35, p. 71). 
facturing industry. In 1907, indeed, a prominent Transvaal builder said that particularly those articles whose production required white labour should be considered for protection, and H.W. Sampson was of the opinion that industries employing a large proportion of Africans were not entitled to protection. ${ }^{45}$ Employers in the building and manufacturing industries regarded the expansion of the white market as an essential precondition for the success of their business ventures and hence tended to think in terms of a "white South Africa". ${ }^{46}$ Of course they also shared with most other whites the belief that white supremacy should be maintained under all circumstances, even though some non-whites should be allowed a certain degree of socioeconomic mobility.

For all these aims and aspirations that white wage earners and buildingtrade employers might share, their immediate interests were frequently in conflict and they clashed over such sensitive issues as the question of coloured skilled labour. Perhaps employers in the Transvaal building industry were prepared to support white labour policies, but not to the point of injuring their own business interests. Moreover, in practice they were rather ambivalent about the position of coloured labour. On the one hand they professed to uphold the interests of the white man, but on the other hand many of them found it difficult to resist the temptation to employ cheaper coloured skilled labour to some extent. Indeed, even within the ranks of the master builders themselves the issue led to some notable controversies. At the Annual Congress of the National Federation in 1907, Transvaal delegates argued that they needed protection against the import of cheap joinery from the coastal towns. They claimed that in Natal "cheap coolie labour" was employed, which was, somewhat unconvincingly, denied by a Natal delegate. Yet what was equally unconvincing was the Transvalers' contention that in the Transvaal "cheap coloured labour is not used in the building trade in any shape or form; not even to drive a nail". ${ }^{47}$ This was in contradiction to the evidence collected by the Transvaal Indigency Commission, and the Johannesburg master builders had perhaps good reasons not to appear before it. Hoewever, when in late 1907 the Transvaal government appointed an Industries Customs Commission to investigate into the state of local industries and report on the advisability of

${ }^{45}$ South African Master Builders' Federation Journal, April 1907, p. 31; TIC, evidence by Sampson, p. 95.

${ }^{46}$ Cf. Bill Freund, "The Social Character of Secondary Industry in South Africa: 1915-1945", in Alan Mabin (ed.), Organisation and Economic Change. Southern African Studies (Johannesburg, 1989), vol. 5, p. 104. Freund rightly criticizes Merle Lipton for suggesting that manufacturers generally opposed racism and segregation - Merle Lipton, Capitalism and Apartheid. South Africa, 1910-1986 (London, 1986), ch. 6.

${ }^{47}$ South African Master Builders' Federation Journal, April 1907, p. 25. See also TIC, evidence by Hodkinson, who said that the coast wood-working industry was mainly carried on with "coolie labour", and that this was "killing" the industry in the Transvaal. 
revising existing custom tariffs, the master builders were quick to give evidence, even though the commission considered it part of its business also to collect data on labour conditions.

Thus it happened that the commission wanted to know to what extent white labour was used in the Transvaal building industry as compared with "coloured labour" - there was no way of evading the question. The secretary of the Johannesburg MBA replied in writing that members of the Association used "a small percentage of coloured labour, i.e. skilled tradesmen". He claimed that about five to ten per cent of contractors outside the Association used "all coloured labour", but that there was "only one member" of the MBA who did the same. For the unskilled labour all masters used coloureds beside Africans, for they found the former were "more reliable"; coloured labourers were paid slightly higher wages than Africans. The MBA's secretary further said that there were "a great many coloured artisans" who were "quite equal to white" and that they were paid the same wages, but that, "taken all round", a coloured man did not get as much wages as a white man. He also claimed that the "largest and best of the employers" did not encourage coloured labour at all. ${ }^{48}$ These statements provide a brief glimpse of patterns of employment in the Transvaal building industry. The policies of the "largest and best" employers notwithstanding (i.e. those who most quickly caught the public eye), it appears that most master builders were employing coloured artisans, although members of the MBA were possibly using a smaller proportion than non-members. MBA members - who were dealing with the trade unions and public opinion more directly than outside contractors - were trying to uphold a "white profile" to protect their reputation and avoid trouble. Interestingly enough, it was admitted that many coloured artisans were just as skilled as their white counterparts, but in the light of other evidence it may be doubted if they were paid the same wages. It is further noteworthy that coloured unskilled labourers, who were apparently considered to be dexterous workers, were in a good position to pick up skills in those trades in which they were usually employed, viz. masonry, plastering and painting. In view of the longstanding artisanal traditions of the coloured people and the fact that many of them had already penetrated the field of skilled labour, it is likely that the "unskilled" ranks were a recruiting ground for the coloured artisan class in the Transvaal.

It is remarkable, to say the least, that the president of the Johannesburg MBA, who was interviewed by the same commission, contradicted the statements of the Association's secretary by claiming that "no coloured labour is employed in the building trades". Instead of providing evidence on labour conditions in the Transvaal, he reverted to the theme of in-

${ }^{48}$ South African Master Builders' Federation Journal, November 1907, p. 17. 
tercolonial competition. Pointing an accusing finger to the Cape and Natal, he said that the "use of coloured or Asiatic labour" in those colonies was prejudicial to the woodworking industry in the Transvaal to the extent that eighty per cent of the work went to the coast. Therefore, he maintained, protection against the competition of the coast colonies with their lower rates of wages and their coloured and Indian labour was needed. What they wanted in the Transvaal was new industries, "so as to build up a big, healthy, contented, white population". Indeed, the MBA's president asserted that new industries in the Transvaal "did not depend on coloured labour", but what they had to depend on was "highly skilled white labour". ${ }^{49}$ It would seem that these statements were an exercise in windowdressing or propaganda rather than anything else. But at the same time there undoubtedly were a number of white labour protagonists among the master builders, and the Transvaal builders and joinery manufacturers were certainly feeling the pressure of competition from the coastal centres. To mobilise support against this competition, which was probably seen as a factor compelling Transvaal builders to engage cheap non-white labour themselves, an appeal to white labour sentiment might be profitable.

The controversy over the question of coloured skilled labour reached a culminating point at the National Federation's Annual Congress in 1908. On this occasion, this "item of far-reaching importance" was reportedly broached for the first time in the way of an open debate. The proposition "to consider the advisability of dispensing with skilled coloured labour" must have been put on the agenda by the socially or ideologically inspired elements among the Transvaal master builders. ${ }^{50}$ The president of the Pretoria MBA, indeed, advocated the introduction of minimum wage legislation, which "would abolish cheap coloured labour, because where a skilled workman was required white men would be selected in preference". ${ }^{51}$ Some years later, this became the very strategy of those white labour protagonists and trade unionists who saw that a policy of direct occupational exclusion did not work. The alternative should be to institute what amounted to a system of wage colour bars by fixing minimum rates of wages at a level on which employers would give preference to whites and non-white labour would consequently be excluded in an indirect way. However, it was evident that the desire to eliminate coloured skilled labour was shared only by a minority of South African builders. The Master Builders' Journal wrote:

It is easier to "consider" dispensing with coloured skilled labour than to effect its removal. All white people have ideals, within the popular definition, of South

49 Ibid., pp. 23-24, quoting Johannesburg newspapers.

so South African Master Builders' Christmas Annual, 1909, p. 21.

${ }^{51}$ Cape Times, April 25, 1908. 
Africa as a white man's country, but it is difficult to conceive how in the march of progress and of education the black man is to be kept a labourer and nothing more or less. ${ }^{52}$

The encroachment of black skilled labour, both coloured and other, was "a question which yearly will grow into greater proportion, calling not for "the desirability of dispensing with coloured skilled labour', but its direction into a channel where it can be used to the fullest extent, and further held up as an exhortation to our white artisan to place his calling on so high a standard that there will be obviously no comparison between the skilled work of black and white". ${ }^{53}$ The debate finally resulted in a resolution that the question should be left to each Association to consider and report on the following year, but in 1909 the question was allowed to again stand over. ${ }^{54}$

The National Federation never decided on a definite policy regarding coloured skilled labour, neither did the Johannesburg MBA. On the one hand lip-service was paid to the special interests of white wage earners (and indeed some builders tended to support the idea of a white labour policy), on the other hand Transvaal employers claimed the right to engage whomever they wanted. Trade union demands like the paying of standard rates of wages were usually acceded to (as far as the bulk of white artisans were concerned), but at the same time skilled coloured men were employed at lower rates of pay. It is therefore not surprising that the Johannesburg MBA was asked by the trade unions time and again to explain the employment of coloured artisans or to assist in eliminating them. The MBA would on occasion profess disagreement with non-white labour executing skilled or semiskilled work, like when they objected in 1906 to the employment of "coloured labour" on cement plaster work on bridges. ${ }^{55}$ In January 1907 the masters went so far as to enquire "whether indeed the Technical College were employing coloured men for teaching joinery", which was shortly afterwards reported not to be the case..$^{56}$ It may be surmised that here trade-union pressure was involved, but it may also be proof of the racial sentiment of employers. The master builders were in any case anxious to maintain friendly relations with organized artisans. At the MBA's Annual

${ }^{52}$ See note 50 .

53 Ibid.

${ }^{54}$ Ibid., p. 26.

55 Johannesburg MBA, General Meeting, April 27, 1906 (Minute Book housed at Office of the Association, Fairview, Johannesburg). It should be noted once again that, in the Transvaal context, it is not always clear whether "coloured" refers to "Cape coloured", or has the connotation of "non-white", "black". Nevertheless, after 1900 there was a growing tendency even in the Transvaal to distinguish between "coloured" and "native", African.

56 Johannesburg MBA, Third Annual General Meeting, 31 January, 1907; Executive Committee Meeting, 19 February 1907. 
General Meeting in 1907 it was reported that the relationship with the trade unions was "most amicable", a claim almost invariably repeated in subsequent years. For all that, relations between masters and men were to be seriously undermined by racially exclusionist demands of white employees and the masters' hesitancy to accede to them.

\section{White trade unions and occupational colour bars}

Exclusionist trade-union demands in the building industry reached a peak between 1910 and 1913. Since August 1908, there was a working agreement in force between the Witwatersrand Trades' and Labour Council, which acted as a coordinating body for the different building unions, and the Johannesburg MBA. By 1910, the MBA was more and more frequently approached by the Trades' and Labour Council "to discuss the matter of coloured skilled labour", as it was rather mildly put in the Association's annual report for that year. In 1911, the question "again caused some considerable anxiety", as it was now more aptly phrased. The MBA went so far as to approach the Minister for the Interior "to see if any legislation could be brought to bear on the matter", most probably a reference to minimum wage legislation which should prevent undercutting from getting out of hand. The Association's report for 1911 further said it was "earnestly hoped" that every member would give "this serious question" the consideration it deserved. ${ }^{57}$ Whatever may have been expected from MBA members, master builders were clearly showing unprecedented concern about the effects of interracial competition on the stability of conditions in the building industry and in particular on their relations with the trade unions. The latter, indeed, were now engaging in direct action.

In the middle of 1910 , organized white labour in Johannesburg attempted a boycott of shops and dwellings built by coloured artisans. It seems that until about that time the employment of coloured skilled labour was largely confined to the suburbs, with the city itself remaining unaffected. Apparently, the "consternation" of white artisans was great when "Cape Coloured" skilled workmen arrived in Johannesburg to execute work here. ${ }^{58}$ In January 1911, a meeting was held "to protest against the encroachment of coloured labour in the skilled trades of South Africa", and when later that year the Trades' and Labour Council was replaced by the more centralistic and effective Transvaal Federation of Trade Unions, the policy of organizing boycotts of concerns or bodies whose buildings had been erected by

${ }^{57}$ MBA, Johannesburg, Seventh Annual Report, 31 December 1910, p. 8; Eight Annual Report, 31 December 1911, p. 8.

${ }^{58}$ R.K. Hallack, "White Labour Policy in South Africa, 1900-1914" (MA thesis, University of Cape Town, 1932), pp. 69-70. 
coloured workmen was tightened up. Thus in January 1912, the Federation was even boycotting a theatre because coloured plasterers had worked on its construction, and it began issuing circular letters calling on the trade unions to boycott coloured workers and all builders, owners and merchants who "sacrificed the heritage of the white people" by employing them. The Transvaal Federation, whose Executive Committee included prominent members of the ASCJ like G. Mason and A. Watson, continued these actions until at least $1913 .{ }^{59}$ In 1916 , after he had been converted to the strategy of "equal pay for equal work", Mason recalled in a lecture how in 1913 the Federation "had initiated an agitation, at his own instigation, against Native and Coloured artisans in Johannesburg and had succeeded in ousting many from the trades here". ${ }^{60}$ Another success for the building workers was that in 1911 the Johannesburg municipal council decided that building plans would only be accepted if white skilled labour was employed. However, in practice it appeared difficult to carry this policy out, and in several cases clauses barring coloured labour were withdrawn on the request of leaders of the coloured community in Johannesburg. ${ }^{61}$

The direct involvement of the Transvaal Federation with labour conditions in the building industry further appeared from its demand in early 1913 that the old Agreement between the Johannesburg MBA and the Trades' and Labour Council should be modified after having been taken over by them. Indeed, it would seem that the Federation was trying to have a "no coloured skilled labour" clause inserted by private contractors just like the municipality had done. Trade-union pressure was undoubtedly behind the passage in the MBA's annual report for 1913 in which members were again urged to give the "question of coloured skilled labour" their serious consideration, as it "vitally affects the whole of South Africa". The MBA was probably trying to prevent master builders from employing an excessive number of coloured artisans and to induce them to pay these men standard rates of wages. It was reported that during 1913 the MBA had again been keeping "a careful eye on any possible legislation". The suggestion to use legislative means to press employers to pay fair wages would indicate that the MBA felt it was unable to control labour conditions in the industry in its own right.

Nevertheless, the MBA noted "with concern" the "move made" at the conference of the South African Labour Party in December $1913 .{ }^{62}$ At this

${ }^{59}$ Edward Roux, Time Longer Than Rope. A History of the Black Man's Struggle for Freedom in South Africa (Madison, 1964), p. 124; Katz, A Trade Union Aristocracy, pp. 234, 262, 265, 292-293 n. 236; Simons and Simons, Class and Colour, p. 128.

${ }^{60}$ Roux, Time Longer Than Rope, p. 146, citing The International.

${ }^{61}$ Hallack, "White Labour Policy", p. 60.

${ }^{62}$ Master Builders and Allied Trades' Association, Johannesburg, Tenth Annual Report, 31 December 1913, p. 9. 
conference a resolution was adopted on the Labour Party's policy with regard to the coloured worker. It was laid down that "it is undesirable to admit coloured persons to membership of the party who have not given practical guarantees that they agree to the Party's policy of upholding and advancing white standards". ${ }^{63}$ The MBA must have read in this a desire to maintain the colour bar against coloured labour (a valid judgement as far as the Transvaal was concerned), for it commented that "it is only by efficient organisation on the part of the employer, combined with highly skilled knowledge on the part of the employee, that the white man can hold his own against the competition of coloured skilled labour". In other words, the Johannesburg master builders rejected colour bars, stressing the conventional business point of view that only a raising of work standards in open competition could ensure the dominant position of the white worker. At the same time, indeed, they professed support for legal measures discountenancing undercutting of white wage standards, although it may be doubted if employers were actually paying standard rates of wages to coloured skilled workers. Indeed, many coloured artisans themselves preferred to work under the trade-union standards with a view to securing employment, a point that will be further discussed below. As it was, a variety of factors the incomplete success of exclusionist trade-union action, the limited leverage of the MBA in controlling employment practices, and the absence of legal pressure to pay minimum rates of wages - led the unions to seek new ways to protect their members.

\section{New strategies and old practices}

The strategy of demanding "equal pay for equal work" (or "the rate for the job"), which formed the basis for the new Cape trade-union policy of incorporating the skilled coloured worker, began to be consistently evolved shortly before the outbreak of World War I. The slogan of "equal pay for equal work" was also raised in the Transvaal, but here it was primarily seen as a device to create wage colour bars, an alternative means of excluding non-white labour. ${ }^{64}$ As early as 1912 , a leading Transvaal trade unionist had declared: "If we get this [a minimum wage fixed according to white standards] the Employer will use white men instead of coloured" ${ }^{65}$ In late 1913, a few pragmatic trade-union leaders in the Transvaal began to defend the new Cape strategy. Among them were G. Mason of the ASCJ and W.H.

${ }^{63}$ Simons and Simons, Class and Colour, p. 163.

${ }^{64}$ E.g. Roux, Time Longer Than Rope, pp. 124-125; Katz, A Trade Union Aristocracy, pp. 354-355.

${ }^{65}$ Katz, A Trade Union Aristocracy, p. 456. 
Andrews, a left-wing member of the Labour Party. Mason, until very recently one of the instigators of the boycotts against coloured labour, now argued that employers should be "taught" to treat the skilled coloureds in the same way as whites, although he admitted that, with equal rates of pay, coloureds would be sacked first. An open organizing strategy might be wise, because by 1913 the white workers' security was "strongly challenged" by the steady advancement of non-whites in semiskilled and even skilled jobs. ${ }^{66}$ Nevertheless, the "new line" was not welcomed in the Transvaal. At a meeting at Germiston in December 1913, Andrews tried to explain to a hostile audience the advantages as well as the limits of the policy of organizing the coloured worker. A Johannesburg newspaper reported:

[he] took care to remind the audience that racial antipathies were not to be flouted, no social intermingling was intended, but rather a logical step in the pursuit of the white ideal by a precaution which prevented the Coloured worker from being exploited by the capitalist to his own evil and to the detriment of the white worker as well. The racial instincts could have their full sway socially, while at the same time they extended to the Coloured man full economic and political equality. ${ }^{67}$

Serious efforts to introduce the new Cape policy also in the Transvaal were soon given up. ${ }^{68}$ Within unions organized on a national basis like the ASJC, there emerged a dividing line between the racially mixed branches in some of the urban centres in the Cape and Natal and the all-white branches in the Transvaal. ${ }^{69}$

This also applied to the Building Workers' Industrial Union (BWIU), formed in 1916-1917 by militant craft unionists who wanted "to bring all sections of workers" in the building industry together in one organization. The BWIU enrolled all kinds of building artisans, but was an industrial union in name only. It organized no black unskilled workers at all, neither in the Cape or Natal, nor in the North. In the Transvaal, with its relatively large number of unskilled whites, some groups of white labourers and supervisors of black labour were recruited, but otherwise the BWIU was largely concerned with the interests of skilled workers. In this respect it

${ }^{66} \mathrm{Katz}$, A Trade Union Aristocracy, pp. 282 n. 100, 358. See also Roux, Time Longer Than Rope, p. 127.

${ }^{67}$ Roux, Time Longer Than Rope, p. 127.

${ }^{68}$ E.g. Cope, Comrade Bill, p. 149.

${ }^{69}$ According to Katz (p. 448) the only craft union in the Transvaal admitting coloureds was the Typographical Union. However, there were hardly any coloured printers in the Transvaal at all, and other evidence reveals that dark-skinned coloureds were in effect excluded from skilled jobs in the printing industry: Archive of the Economic and Wage Commission, evidence by African National League, Johannesburg. 
followed the same organizing policies as the other building trade unions - in the Eastern Cape and Natal a good deal of pragmatic non-racialism, in the northern provinces white exclusionism. ${ }^{70}$ At the third congress of the South African Industrial Federation (SAIF), the successor to the Transvaal Federation, in May 1919, the BWIU and ASCJ delegates were leading spokesmen for the "pragmatic wing" of the white trade-union movement which supported a policy of incorporation of the skilled coloured worker in the Cape and Natal. They argued that in the coastal centres trade-union branches were "forced" to organize coloured artisans in order to protect themselves and that there was a difference between the coloured man and the African (who was not enrolled anyhow). However, significantly enough, the same arguments were not used with regard to the Transvaal. ${ }^{71}$ Thus, the BWIU and ASCJ - by far the two most important unions in the building industry - developed a flexible but opportunistic "dual strategy". For reasons of expediency, i.e. to enforce full rates of wages allround, their branches in centres like Port Elizabeth and Durban were organizing coloured skilled workers, while in the Transvaal an uncompromising stance against coloured tradesmen was maintained. All this did not mean that there was no race prejudice at the coast. That there was a strong prejudice appeared, among other things, from the preference of white trade unionists in a town like Pietermaritzburg for separate branches for coloureds, and from the fact that in East London coloured artisans were not admitted to the building trade unions at all. ${ }^{72}$

Meanwhile, trade-union efforts to impose occupational colour bars were continued. White workers on the Rand complained of "coloured and kaffir labour doing skilled work" in the building trade. ${ }^{73}$ On the Witwatersrand Building Trades Joint Board, a conciliation board claiming it wanted to "clean up" the building industry, the trade unions were constantly lodging complaints about the employment of coloured labour. In October 1918, for

70 Amalgamated Society of Carpenters and Joiners' Monthly Report (Johannesburg), June, 1916, p. 12; Gitsham and Trembath, Labour Organisation, pp. 71-3, 162-163, 171, 178; Simons and Simons, Class and Colour, p. 197; Records of the Trade Union Council of South Africa (hereafter: TUCSA), SAIF, Bc 8, Bd 2; Records of the Garment Workers Union (hereafter: GWU), Dba 66: Constitution of the Building Workers' Industrial Union of South Africa (1947). On BWIU activity among unskilled whites, see in particular TUCSA, SAIF, Bc 1.2; GWU, Dba 11; Master Builders and Allied Trades Association of the Witwatersrand, Annual Report, 1922, p. 12.

${ }^{71}$ Report of Special Trade Union Congress, held at Bloemfontein, May 5-9, 1919 (Archive of the Department of Mines and Industries, MNW 474 - National Archives, Pretoria).

7 TUCSA, SATUC, Ca 1.4, report of South African Trade Union Congress, March 1929 ; Cc 6.3, correspondence September 1928; Cc 1.5, correspondence August-October 1928.

73 TUCSA, SAIF, Ba 1.1. 
example, W. Blake, the general secretary of the BWIU, and others complained of the employment of "cheap coloured" painters, plasterers and other artisans, and the Benoni branch of the BWIU even reported a case of an African being employed on "skilled painting". The Joint Board - in which the unions held a very strong position - endeavoured to control the building industry in the widest sense of the term. Not only building firms but estate agents and even householders were blacklisted and threatened with strong action being taken against them if they did not comply with the provisions of the working agreement in the industry or employed coloureds as painters, plasterers or bricklayers. Remarkably enough, there was not a single suggestion made by the trade unions that a sensible way of helping to establish effective control over wages and conditions would be to organize the coloured skilled worker. Instead, the unions represented on the SAIF's "Department of Building Industry" tried to solve their problems by deciding that from the first of January, 1919, they would no longer work with non-union men. ${ }^{74}$ However, the elimination of non-union and non-white labour was not accomplished. Watertight closed shop arrangements were not agreed to by the employers and at any rate difficult to enforce in the rather chaotic and dispersed building industry. For this reason, non-white labour competition remained an almost uncontrollable problem for white building workers. During the next twenty years, the Transvaal branches of the BWIU continued to complain of coloureds - and even Africans - being employed on skilled work in the building industry, as well as in the mines and other industries where the union had members. ${ }^{75}$

The inability of the unions to enforce a closed shop or the elimination of coloured skilled labour did not mean that they were too weak to wrest any concessions from the masters. On the contrary, the building workers were the first body of employees in South Africa to gain a notable reduction in working hours. On February 1, 1919, the white building workers of the Rand and Pretoria came out on strike to enforce their demands for a fourty-four-hour working week and a rise in artisan wages. The action resulted in a period of idleness in the Transvaal building industry which lasted for three months, being one of the longest strikes in the history of South Africa. ${ }^{76}$ An interesting and revealing feature of the strike was the role and position of coloured building workers. They were inevitably con-

${ }^{74}$ TUCSA, SAIF, Ba 6.2, Ba 6.3; Simons and Simons, Class and Colour, p. 228.

${ }^{75}$ E.g. TUCSA, SATUC, Cc 1.5, C.B. Tyler to Secretary SATUC, 5.11.28; SATLC, Dc 2.8, W. Blake to C.B. Tyler, 13.11.34, and C.B. Tyler to Secretary SATLC, 4.3.35. See also The Building Worker, Official Organ of the BWIU of South Africa, June 1940, pp. 2-3.

${ }^{76}$ Gitsham and Trembath, Labour Organisation, p. 21; I.L. Walker and B. Weinbren, 2.000 Casualties. A History of the Trade Unions and the Labour Movement in the Union of South Africa (Johannesburg, 1961), p. 190. 
cerned in the strike as well, but it is not entirely clear whether they were forced to come out or downed tools voluntarily. However, as to the result of these events there can be no doubt. The strike led to the near-starvation of large numbers of coloured people, building-trade workers and their families, in the Transvaal. After they had ceased work, the coloured men were ignored by the white strikers and simply left to themselves, without any provision being made for them from trade-union funds or otherwise. The situation became so bad, that the Mayor of Johannesburg contacted the headquarters of the African Political Organisation (APO - a coloured organization) for financial assistance to take relief measures. The APO called a meeting at Cape Town to discuss the question and "to protest against the actions of the white Trade Unions of the Rand". Dr. Abdullah Abdurahman, the APO's leader, spoke of "terrorism" of the white trade unions, which refused to admit the coloured workers as members but forced them to cease work and then left hundreds of coloured people starving. Abdurahman, who said that between four-hundred and five-hundred coloured men at least were employed in the building industry in Johannesburg, reportedly exclaimed: "If any disgraceful act had ever been done in this country by white men, this surely was the worst. It was worse than the Germans would have done." He further asserted that: "This suffering of the coloured people was only part of the persecution going on for some time in Johannesburg" by white trade unionists, "whose underlying spirit was to keep the coloured man out of the Unions." 77

According to a prominent Cape Town coloured trade unionist, coloured people in the Transvaal were being denied the right to earn a living, "simply because they were not white". If things were run on fair lines, he said, coloured men would be willing "to help the whites in disputes such as this". Another speaker at the APO meeting, indeed, maintained that the coloured building workers had not been forced to cease work, but had come out in sympathy, "and now they saw the result". He said "They thought that by downing their tools they would for ever remove the "colour bar"", only to find out they were betrayed. ${ }^{78} \mathrm{On}$ March 24, it was reported that 171 coloured men, "many of them with large families", were depending on relief, and that a further appeal was made for financial assistance to coloured artisans in the building trades. ${ }^{79}$ Such was the lot of coloured workers who suffered rejection at the hands of white labour.

78 Ibid.

${ }^{79}$ Cape Times, 24 March 1919. 


\section{Wage colour bars and the Industrial Conciliation Act}

In 1920, Abdurahman asserted that because white trade unions in the Transvaal tried to keep out coloured workers from skilled occupations, they were forced to work for a lower wage in order to find employment, which was then used as a pretext for barring them from the unions. ${ }^{80}$ Perhaps this exclusionist policy was detrimental to the white workers themselves; it certainly did not help them to put an end to the presence of black labour. In March 1924, indeed, some prominent trade unionists observed:

All along the Witwatersrand this elimination of the white worker is going on at no mean pace; rows of buildings are being erected by cheap coloured labour; the number of native chauffeurs increases daily; and on the mines, natives are performing clerical work, working as pipefitters, driving locomotives, pumps, etc. [ . . ] unless organised labour - in combination with other citizens - can arrest the present day tendency there will be very few white workers on the Witwatersrand in ten years time $\left[\ldots .{ }^{81}\right.$

Shortly afterwards the Industrial Conciliation Act was passed, which inaugurated a new era in South African labour relations. Among other things, the Act provided for the establishment of industrial councils of employers and employees to conclude agreements on wages and working conditions which could be made legally binding by the Minister of Labour. This created new possibilities to enforce the "rate for the job", and the unions were not slow to take advantage of it. Unlike "pass-bearing Natives", who did not fall under the definition of "employee", coloureds and the majority of Indians fell within the scope of operation of the Industrial Conciliation Act, but just because of this it was illegal to pay them lower wages than whites in scheduled (almost exclusively skilled) occupations. The building industry was one of the first industries in South Africa to take advantage of the Act by establishing a National Industrial Council of employers and (white) employees. The first National Agreement in the building industry was concluded in March 1925, fixing standard rates of wages for skilled classes of work, which were legally recognized on the Council's request. The consequences of this step were recorded by the Economic and Wage Commission which collected evidence on economic conditions in South Africa during the same year. In various centres across the country, from small towns like Kingwilliamstown in the Eastern Cape to major cities like Johannesburg, the legalization of wages in the building industry - which rendered underpayment of workers a contravention of the law - led to the dismissal of coloured artisans.

Simons and Simons, Class and Colour, p. 247.

${ }^{81}$ GWU, Aab 2.6. 
Some of the evidence submitted to the Economic and Wage Commission is of great interest. Mr. H.R. Morgan, who gave evidence on behalf of the Kingwilliamstown branch of the APO, testified that since local master builders had to pay standard rates of wages to all artisans under the legally enforced industrial agreement, many coloured workers had lost their employment. Morgan explained that "the white man would always employ a man of his own colour, other things being equal". ${ }^{82}$ An ironical result of this development was that many of the dismissed coloured men were now entering the market as small "contractors" undertaking jobs on their own. In their new capacity of independent workmen taking contracts for labour only, they were yet again working under the standard rate. Morgan denied that coloureds were replaced by whites because they were less skilled. He maintained they were "quite competent" and said that many whites who were getting high wages compared to the coloureds were only semiskilled. In other words, it was a question of colour rather than skill. Morgan also complained that coloured skilled workers in Kingwilliamstown and East London were not admitted to the building trade unions, although they lived on the same level as whites. He himself had several times applied for membership of the East London branch of the BWIU, but was refused on each occasion. He claimed that white trade unionists were not prepared to work alongside coloured men, even if they received the same rate of pay. Therefore, coloured workers had organized themselves in the local branch of the APO, which had about two-hundred members, including building artisans and factory operatives. ${ }^{83}$

In Kimberley, the result of the legalization of the National Agreement in the building industry was much the same: large numbers of coloured building workers were dismissed by the employers, who used the argument that they were not efficient enough to earn the standard rate of $3 \mathrm{~s} .4 \mathrm{~d}$. per hour. But as a witness from Kimberley put it to the commission, why did they employ coloured men if they were inefficient, up to the time of the agreement? Only now that the new legal rate came in force, it was said that coloured skilled workers were inefficient. According to the Kimberley Trades and Labour Council, coloured artisans in the local building industry used to get lower wages than whites, "chiefly because of their colour, not skill". ${ }^{84}$ The mechanism of the wage colour bar could also be used to

${ }^{82}$ Archive of the Economic and Wage Commission (hereafter: AEWC), National Archives, Pretoria: memorandum by H.R. Morgan, 12.10.25.

${ }^{83}$ AEWC, evidence by H.R. Morgan, Kingwilliamstown, 4440jj-4440uu; memorandum by Morgan.

${ }^{84}$ Report of the Economic and Wage Commission, Pretoria 1926 (U.G. 14-'26), pp. 290-291; AEWC, report submitted by the Kimberley and District Trades and Labour Council. It would seem that trade-union policies in Kimberley were more like those in the Transvaal than in the coastal centres. 
exclude Africans. As the commission pointed out, the result of a high minimum rate in a skilled craft or occupation would be that "even the exceptional native, whose efficiency would justify his employment at the high rate, would be excluded by the pressure of public opinion, which makes it difficult to retain a native in an employment mainly reserved for Europeans". ${ }^{85}$

In Johannesburg, the commission interviewed representatives of the Afrikaanse Nasionale Bond (African National League - ANB), a political rival of the APO which held a position of some influence among the coloured working class on the Witwatersrand. In contrast to the APO, the ANB stressed the primacy of promoting the coloured people's "industrial advancement" rather than their political rights. The majority of its members were artisans (especially in the building industry), and they claimed they had about five-hundred members in the Transvaal. They testified that coloured skilled men in the Transvaal building industry were denied membership of the trade unions and frustrated in their efforts to get employment, notwithstanding the fact that their skill was "of a very high order and in a large percentage of cases, as high as that of white skilled workers". They said "very considerable friction" had occurred between white and coloured artisans in the building industry, referring to the strike of 1919 when coloured men "were pulled out of their jobs under duress and threats of violence" and coloured families were on the brink of starvation. Evidently, these events had made a great impression and were still fresh in the coloured people's minds. The ANB witnesses further said they would favour a minimum wage, irrespective of colour, if this went hand in hand with equality of opportunity for all workers, including equal facilities for technical training and apprenticeship of coloured boys. The coloured people demanded fair play and "relief from the artificial barriers designed to shut them out from equality of opportunity and retain them under a ban of helotage". 86

Like elsewhere, the legalization of the new Agreement in the building industry - which the ANB saw as an attempt to oust the coloured workers had resulted in a large number of coloured men being thrown out of work. It was claimed that in particular those jobs where coloured men were employed were traced by officials of the Industrial Council, and that the unions were busy pressing employers to discharge coloured workers who were not paid the standard rate and threatening to boycott firms which supplied

${ }^{85}$ Report of the Economic and Wage Commission, p. 124.

${ }^{86}$ AEWC, memorandum by ANB, Johannesburg, September 1925; evidence by Messrs. Rev. J.A. Rogers, G.W. Crowe, R.A. Goodman, J.W. Ontong and G.S. Rasdien, Johannesburg, 3141-3190. According to the ANB witnesses there were some 8,000 coloured people in the municipal area of Johannesburg, and 32,000 in the Transvaal Province. 
materials to contractors who employed coloured labour. The average wage of a coloured skilled workman was said to be $£ 5$ per week, which was equal to about seventy per cent of the legal rate of $3 \mathrm{~s} .4 \mathrm{~d}$. per hour fixed for all artisans except painters. Coloured workers, indeed, felt they were forced by social and economic pressure to sell their labour at a cheaper rate than the whites. If they were to accept the same rate of pay "the vast majority of the coloured workmen would never be employed no matter what their efficiency may be, in view of the existing prejudice against the employment of coloured persons". For one thing, the coloured worker objected to the principle of equal pay for equal work "because in those circumstances the white employer would rather employ the white man than a coloured man". For another, "even if the employer is prepared to pay the coloured worker the same wages as the white worker the white worker will not work alongside the coloured man in the Transvaal". ${ }^{87}$ This claim was corroborated by evidence submitted by C.B. Tyler, the general secretary of the BWIU. Tyler explained to the commission that in the Transvaal coloured workers were not taken into the BWIU as "unfortunately it is the prejudice of the white workers in the Transvaal that they would object to a coloured man working on the same job as themselves, even if he got the same money". This attitude also entailed that coloured members of the BWIU in the coastal centres could not transfer to branches in the Transvaal. ${ }^{88}$.

However, the position was even more intricate than that. According to the ANB witnesses, there was a fair amount of what could best be described as "occupational passing". They maintained that, whereas "qualified coloured skilled workers" who applied for admission to the unions were definitely refused (i.e., as "coloureds"), some of those coloured men who were both highly skilled and only slightly coloured were "made white" and taken as members into the union. The ANB indeed disapproved of this, for "when you have pride of race, and want to stay with your colour and remain what you are (because you will always be a coloured man)", it was not in your interest to pass for white. Occupational passing was seen by the ANB as part of the trade unions' effort to oust the coloured skilled man from the building industry. Coloured workers who passed for white did "not remain loyal to their own people", had "to play white" and became themselves a party to discriminatory actions against coloured labour. Indeed, an example was given of a representative of the BWIU - who the ANB witnesses claimed was actually a coloured man - who had been sent to an employer who had coloured men working for him and "suggested to him that in view

${ }^{87}$ AEWC, evidence by Rogers, Crowe, Goodman, Ontong and Rasdien.

${ }_{88}$ AEWC, evidence by Tyler, Johannesburg, 1180-1198a; TUCSA, SATUC, Ca 1.4, report of South African Trade Union Congress, March 1929. Tyler belonged to the small group of progressive white trade union leaders, who were more enlightened on racial matters than their own rank and file. 
of the fact that he had to pay $3 / 4$ per hour to both white and coloured men he [the employer] should be sufficiently patriotic to replace his coloured workers by white men". ${ }^{89}$ To such heartbreaking absurdities the social and economic colour bar could apparently lead.

The ANB had a clear perception of the change in trade-union strategy. They regarded the legalized rate of wages as a device to exclude the coloured worker from the skilled trades:

It is a colour bar. We think that the trades unions have for many years tried to oust the coloured worker and at last they have dropped down on a different basis - equal pay for equal work. We think that the existing labour policy is the result of the discovery that this would be the best means of ousting the coloured man from the trade..$^{90}$

They admitted that practically no coloured skilled man earned the standard rate and that they were generally employed by masters who were not members of the MBA, including a number of coloured contractors. The number of coloured artisans employed by MBA members would indeed appear to have decreased substantially since the legalization of skilled wages, at least during the first few months following the inauguration of this novelty. Like in other centres, in Johannesburg the creation of a mass of small coloured "contractors" was anticipated, men who would have to undertake work at piece rates and be placed in a worse position than coloured artisans employed by others. ${ }^{91}$ In any case, under conditions of unequal opportunity the coloured artisan would generally not be inclined to demand equal pay of his own accord. He was still faced with the dilemma either to undercut the white man in order to get a job, or not to be employed at all. The first possibility continued to be a feasible option.

Although C.B. Tyler maintained that in the Transvaal coloured artisans were mostly employed on house-building undertaken by small, often "unscrupulous", contractors who were not members of the MBA, while large jobs executed for the Public Works Department were less affected, ${ }^{92}$ they remained a serious problem for white building workers. Even if MBA members employed less coloured labour than before, there were still a considerable number of non-members (and even members) who evaded the terms of the National Agreement and the legal rates of wages. Thus the coloured artisan class was being kept alive and the white trade unions continued to be confronted with the question of how to deal with them. The problem was compounded by the competition of Africans, some of whom

${ }^{89}$ See note 87 .

90 Ibid.

91 Ibid.

92 AEWC, memorandum by BWIU, 20.8.25. 
were employed in relatively skilled jobs. Since Africans were not covered by the agreements in the building industry, they could be engaged at lower than the legal rates of pay. In order to halt this tendency, the BWIU and other unions pressed for an amendment to the Industrial Conciliation Act empowering the Minister of Labour to extend the terms of wage agreements to Africans. In 1930, an amendment to this effect was introduced..$^{93}$

Nevertheless, despite the closing of some of the loopholes in the Industrial Conciliation Act, underpayment of workers of all classes continued on a large scale. How widespread breaches of agreements in the building industry were, was even shown by official figures of the Labour Department. Especially after 1932, when the National Industrial Council was dissolved and replaced by a number of local councils, evasion of agreements was rife. During the years 1934-1938, the number of prosecutions for contravention of agreements in the building industry often amounted to more than half of the total number of prosecutions instituted under the Industrial Conciliation Act. In 1934, 147 out of 311 prosecutions were in the building industry; by 1938 , this had increased to not less than 344 out of a total of $586 .{ }^{94} \mathrm{~A}$ large number of these were for underpayment of workers, and a close examination would undoubtedly reveal that particularly non-white workers were involved. Indeed, it happened that employers and employees were colluding in evading the legal rates of wages. Obviously, as long as the trade unions were refusing to organize non-white workers, their control over the supply of labour was rather tenuous.

In 1938,412 coloureds were reported to be covered by the local industrial council agreement in Johannesburg and Pretoria. ${ }^{95}$ Perhaps this was the number being paid the legal rate of wages, or the number officially registered by builders and contractors, but it was only a visible top section of coloured building workers in the Southern Transvaal. In any case, after more than four decades of struggle against coloured labour competition, organized white workers in the Transvaal had not succeeded in eradicating it. Rather than to solve the problem by organizing their black fellowworkers, white building workers stuck to their exclusionist aims and practices, and to their race prejudice and vision of a "white South Africa".

${ }^{93}$ As a result, by 1938 fifty-five per cent of the 46,130 workers in the building industry covered by agreements under the Industrial Conciliation Act in the seven largest cities were African. By this time semiskilled and unskilled workers were provided for in the agreements as well. Annual Report of the Department of Labour for the Year 1938, p. 53; Report of the Industrial Legislation Commission (U.G. 37-'35), p. 15.

94 Annual Report of the Department of Labour for the years 1934-38.

95 Annual Report of the Department of Labour for the Year 1938, p. 53. 


\section{Conclusions}

White building trade unions in the Transvaal were not just concerned with protecting their members against cheap, "unfair" competition, but with resisting any kind of skilled non-white labour as such. The particular hostility of the Transvaal trade-union movement towards black labour resulted from the fact that - in contrast to the Cape - white workers had at first enjoyed a virtual monopoly of skilled labour, and then saw this being undermined by coloured competition. In addition, a larger number of whites were employed in semiskilled and unskilled jobs than elsewhere in South Africa, which rendered the experience of interracial competition even more dramatic. ${ }^{96}$ The skilled occupations, and even some of the lesser skilled jobs, were seen as the heritage and exclusive preserve of the whites. That the unions were actuated by an unqualified racial prejudice appears, among other things, from their refusal to admit coloured artisans as members (trade-union colour bars) and their efforts to prevent non-whites from acquiring skills and to bar them from skilled occupations (occupational colour bars). ${ }^{97}$

By the 1930s, it is true, there were a handful of Transvaal trade unions in manufacturing industry which saw no other way to solve the problem of interracial competition but to follow the Cape strategy of enrolling coloured workers, including unions of leather workers, furniture makers and garment workers (who organized coloureds in a parallel branch). ${ }^{98}$ But unions in such important industries as mining, building and engineering clung to the policy of white exclusionism, despite the presence of a substantial group of coloured skilled and semiskilled workers. Notwithstanding the social and economic proximity of coloured workers (and to a lesser extent of Indians and "detribalized" Africans), racial prejudice was hardly broken down but perhaps rather strengthened by intensified interracial competition. While it might be argued that, as manifestations of race prejudice, white exclusionism and racial discrimination had a "rational" meaning inasmuch as they found a basis in well-defined economic interests, there was clearly a good deal of "irrationality" in the refusal to organize coloured artisans. This does not mean that in those trades in the Cape and Natal where white trade unionists deemed it imperative to enrol coloured workers prejudice was non-existent. It would rather seem that race preju-

* See for a recent account of the evolution of the policies and ideology of organized white labour during the pre-World War I period Pieter van Duin, "South Africa", in Marcel van der Linden and Jürgen Rojahn (eds), The Formation of Labour Movements 1870-1914. An International Perspective, 2 vols (Leiden, 1990), 2, pp. 623-653.

${ }^{7}$ Cf. Katz, A Trade Union Aristocracy, p. 448, who arrives at similar conclusions.

- Lewis, Industrialisation and Trade Union Organisation, Ch. 4; E.S. Sachs, Rebels' Daughters (London, 1957), pp. 118-120. 
dice did not necessarily lead to overt discrimination - it would not if the consequences of this were considered to be overwhelmingly counterproductive - although it did so in most cases.

That patterns of racial discrimination were "rationally" moulded and remoulded according to the (changing) needs of the situation was shown by the shift from a strategy of occupational colour bars to one of wage colour bars. This happened first in the coastal centres, but after the introduction of the Industrial Conciliation Act also in the Transvaal. The trade unions' attempts to "terrorize" employers into dispensing with coloured skilled labour were far from completely successful, although the policy of fixing and maintaining minimum rates of wages received at least nominal support from organized master builders. That even legalized wages could not oust the coloured artisan class from the Transvaal labour market was due to the deficient control over labour conditions exerted by industrial councils and the organizations of employers and employees, to the resultant large-scale evasion of the terms of industrial agreements, and to the keen awareness of coloured building workers that a policy of equal wages regardless of colour would lead - at least in the Transvaal - to their elimination from the skilled occupations. Indeed, the tragedy of the situation in the South African labour market was that the discriminated group itself helped to sustain split labour market conditions and thus, to some extent, the racial division in the working class. This was because they realized that as long as race prejudice and inequality of opportunity ruled supreme in South African society, their would be no point in demanding equal wages, which would act as a mechanism of exclusion in the labour market. Of course, the fears underlying this attitude were speculated on and abused by employers, while white trade unionists used it as an argument to emphasize their point of the evil consequences of coloured labour competition.

Thus, the vicious circle of race prejudice, economic discrimination, undercutting of wages and white exclusionism continued to determine conditions in the labour market. To phase out interracial competition altogether, a more radical policy of State intervention and government imposed job reservation would be required. But this belonged to a later period in South African history. 